\title{
Community Participation in Development of Ecotourism in Taman Beach, Pacitan District
}

\author{
Heru Wiwoho Supadi Putra ${ }^{1 *}$, Abdul Hakim², Harsuko Riniwati ${ }^{2}$, Amin Setyo Leksono ${ }^{2}$ \\ ${ }^{1}$ Doctoral Program of Environmental Sciences, Postgraduate School, University of Brawijaya, Malang, Indonesia \\ 2Postgraduate School of Environmental Sciences, University of Brawijaya, Malang, Indonesia
}

\begin{abstract}
Taman Beach as one of the superior tourist destinations in Pacitan has now begun to develop. The development of Taman Beach tourism object is inseparable from the efforts which are initiated by the Group of Turtle Rescue Society for Tourism "Taman Ria"which develops turtle conservation activities through the concept of community-based ecotourism. Local people have also developed tourist attractions such as flying fox and swimming pools to attract tourists to visit it and a portion of the tourism incomes for the funding of turtle conservation activities. However, in the development process, there are problems such as the low level of community participation and the lack of management of tourist object that is integrated with the local community. This study aims to analyze the role and level of community participation in supporting the development of community-based ecotourism in the Taman Beach area. The method used in this research is descriptive quantitative. Quantitative data analysis using the Multidimensional Scaling (MDS) approach. Data collection is done by using questionnaires and observations in the field. The variables studied included the dimensions of planning, management, monitoring, and supervision. The results of the study indicate that the involvement of local communities in the development of ecotourism does not support sustainability, with an average sustainability index value of 46.864 . The level of community participation according to Arnstein's participatory ladder from the aspect of planning and management aspects has reached the level of placement participation in the tokenism category (accepting the provisions). Whereas from the aspect of monitoring and controlling has reached the level of consultation participation in the tokenism category (accepting the provisions). The results of the analysis show that policy strategies are needed to increase community participation through increasing community roles and responsibilities in planning, management, monitoring, and controlling.
\end{abstract}

Keywords: community based, ecotourism, multidimensional scaling

\section{INTRODUCTION}

Community-based ecotourism is a pattern of ecotourism development that supports and enables full involvement of local communities in the planning, management, monitoring and controlling of ecotourism businesses and all the benefits obtained. Community-based ecotourism is an ecotourism business that focuses on the active role of the community. Community-based ecotourism patterns recognize the right of local communities to manage tourism activities in areas that they have customarily or in other words as managers $[1,2,3]$.

Taman Beach is one of the beaches in Pacitan Regency. One of the tourist attractions in Taman Beach is as a place for turtle conservation. This conservation is supported by the beauty of pristine beaches and the development of tourist attractions in the form of flying fox and

\footnotetext{
*Correspondence address:

Heru Wiwoho Supadi Putra

Email : heru.wiwoho.supadi.putra@gmail.com

Address : Postgraduate School, University of Brawijaya, Mayjen Haryono 169, Malang, 65145
}

swimming pools. With this potential, Taman Beach can be developed in an effort to improve the economy and people's welfare. These efforts are carried out with the concept of sustainable development to minimize environmental damage in accordance with the concept of ecotourism combined with community-based ecotourism.

Strategies for developing ecotourism and involving community participation will be effective if the community is given a maximum role in its management [4]. Through the development of community participation, it will provide regional economic growth and better competition in sustainable development. The lack of development of Taman Beach as an ecotourism destination is caused by the concept of communiy-based tourism has not been applied optimally.

One strategy to develop the concept of community based ecotourism (CBE) is to place local communities around tourist objects as regulators who have complete control of tourist objects. Therefore, the community can benefit from the existence of tourism objects through improved welfare $[5,6]$. According to Himberg 
[7], the main component in active community participation is involvement in initiation and decision making.

There are four stages of community-based ecotourism planning processes: the assessment and preparation of community organizations, planning and preparation, delivery, and monitoring-evaluation [8]. Community-based ecotourism planning has involved community participation from the beginning, starting from the assessment and preparation of community organizations to the last stage. It is clear that community involvement in ecotourism development is very important and a major part of the success of the concept of communitybased ecotourism.

Community participation in the development of ecotourism has different levels, depending on the role of the community. Arnstein [9], through its typology known as the level of community participation (the ladder of citizen participation) describes the level of community participation based on community strength to determine the final product. Arnstein explained that community participation is described in a multilevel pattern which is divided into eight levels grouped into three categories as shown in Figure 1.

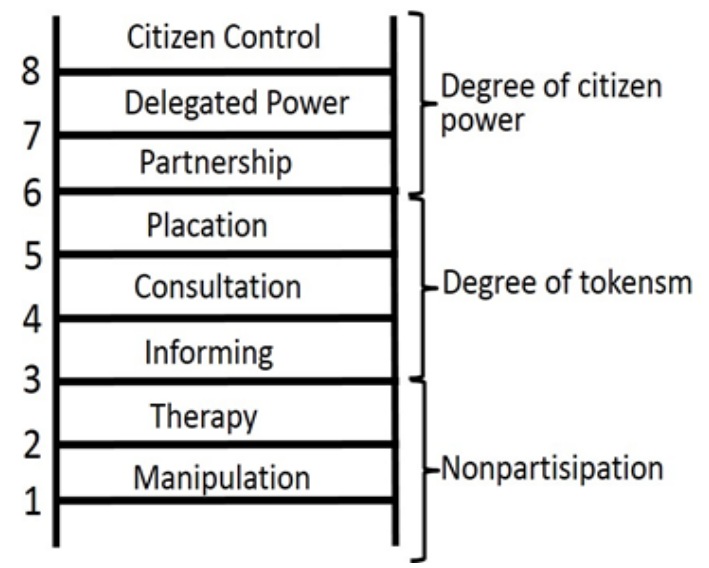

Figure 1.Level of Community Participation [9]

This research is important because it aims to analyze the role and level of community participation in developing the concept of sustainable ecotourism at Taman Beach as a superior tourist object. Thus, it can increase tourist visits and can increase the income of communities around the tourism area and Pacitan.

\section{MATERIAL AND METHOD}

The method used in this study is descriptive quantitative, supplemented by information through in-depth interviews (in-depth interviews) and direct observation in the field to support and sharpen quantitative analysis. Data collection was obtained directly from the field through questionnaires and direct observation and Focus Group Discussion (FGD) both to respondents and informants.

The population in this study is the community around Taman Beach and stakeholders who are directly involved with the development of ecotourism in the coastal area of Taman Beach. Sampling used nonprobability sampling technique. The respondent's collection procedure was carried out by purposive sampling technique. The number of samples was determined using the Slovin formula with a deviation rate of $10 \%$. Based on the calculation results, the number of samples was 88 respondents with the following calculations:

$$
n=\frac{N}{1+N \cdot e^{2}}=\frac{686}{1+686(0,1)^{2}}=87,27(88)
$$

Data analysis in this study was carried out with quantitative descriptive analysis techniques using the Multidimensional Scaling (MDS) analysis method. There are several steps to analyzing using MDS. First, determine in advance the dimensions and attributes of sustainability. Second, giving a score for each attribute, giving scores on each attribute can describe the sustainability conditions of each dimension, whether good or bad. The third stage, RAPFISH ordination with the aim of determining one point (value) that can describe the relative position of each dimension with the value of stress (S) and the coefficient of determination $\left(R^{2}\right)$ to measure the goodness of fit. Good analysis results are shown with stress values smaller than 0.25 (S $<0.25$ ) and higher $R^{2}$ values. Fourth, determining the sustainability status of management using the sustainability category refers to Table 1 . The next stage is the Montecarlo analysis which is used to determine the stability of the results of the RAPFISH ordination. The final step is leverage analysis to find out the sensitive attributes of each dimension.

In this analysis, three dimensions are used: planning, management, monitoring and controlling dimensions. The number of attributes for each dimension can be seen in Table 2 . 
Table 1. Category of Sustainable Status[9]

\begin{tabular}{llll}
\hline No. & $\begin{array}{c}\text { Dimension } \\
\text { Index Value }\end{array}$ & Category & \multicolumn{1}{c}{ Keys } \\
\hline 1 & $00.00-24.99$ & Bad & Not Sustainable \\
2 & $25.00-49.99$ & Less & Less Sustainable \\
3 & $50.00-74.99$ & Enough & $\begin{array}{l}\text { Enough Sustainable } \\
4\end{array}$ \\
$75.00-100.00$ & Good & Sustainable \\
\hline
\end{tabular}

Table 2. Number of Attributes in Dimension of Sustainability Roles and Levels of Community Participation

\begin{tabular}{lll} 
No & Dimension & Attribute number \\
\hline 1 & Planning & 16 \\
2 & Management & 16 \\
3 & Monitoring and Controlling & 8 \\
\hline & Total & $\mathbf{4 0}$
\end{tabular}

\section{RESULT AND DISCUSSION}

The results of the accuracy test of MDSRapfish analysis are reviewed from the Stress and $\mathrm{R}$-square values for the three dimensions used as shown in Table 3.

Table 3. Summary of Feasibility Results/Goodness of MDS-Rapfish Analysis Management of Ecotourism in Taman Beach

\begin{tabular}{lcc}
\hline \multicolumn{1}{c}{ Dimension } & Stress $(\boldsymbol{S})$ & $\boldsymbol{R}$-Square (R) \\
\hline Planning & 0,195 & 0,904 \\
Management & 0,178 & 0,908 \\
Monitoring and & 0,227 & 0,902 \\
Controlling & & \\
\hline
\end{tabular}

Based on Table 3, it can be seen that the value of stress of all dimension values smaller than 0.25 and the third value of R-Square each dimension above 0.90. It can be said that MDS analysis meets the Goodness-of-fit criteria. This is quite accurate and feasible to be further discussed and analyzed.

\section{Index and Sustainability Status of the Planning Dimension}

The results of the ordination analysis with MDS-RAPFISH indicate that the planning dimension has a sustainability index value of 40.566, as shown in Figure 2. The index value is in the range of $25.00-49.99$, which means that this dimension is less sustainable. In other words, the involvement of community participation in supporting ecotourism development seen from the planning dimension in the research area is less support for sustainability.

Based on the results of the Leverage analysis three attributes were sensitive to the sustainability index value of the planning dimension : 1) the community could submit proposals in planning ecotourism development, but had very little opportunity to influence the program to be implemented, 2) the community could submit proposals in planning ecotourism development, but there is no guarantee that the idea will be realized in the program to be implemented, 3) the community only gets information on ecotourism development planning in the coastal area of the Park, but there is no opportunity for joint decisions (discussions are conducted in one direction). Leverage analysis results can be seen in Figure 3.

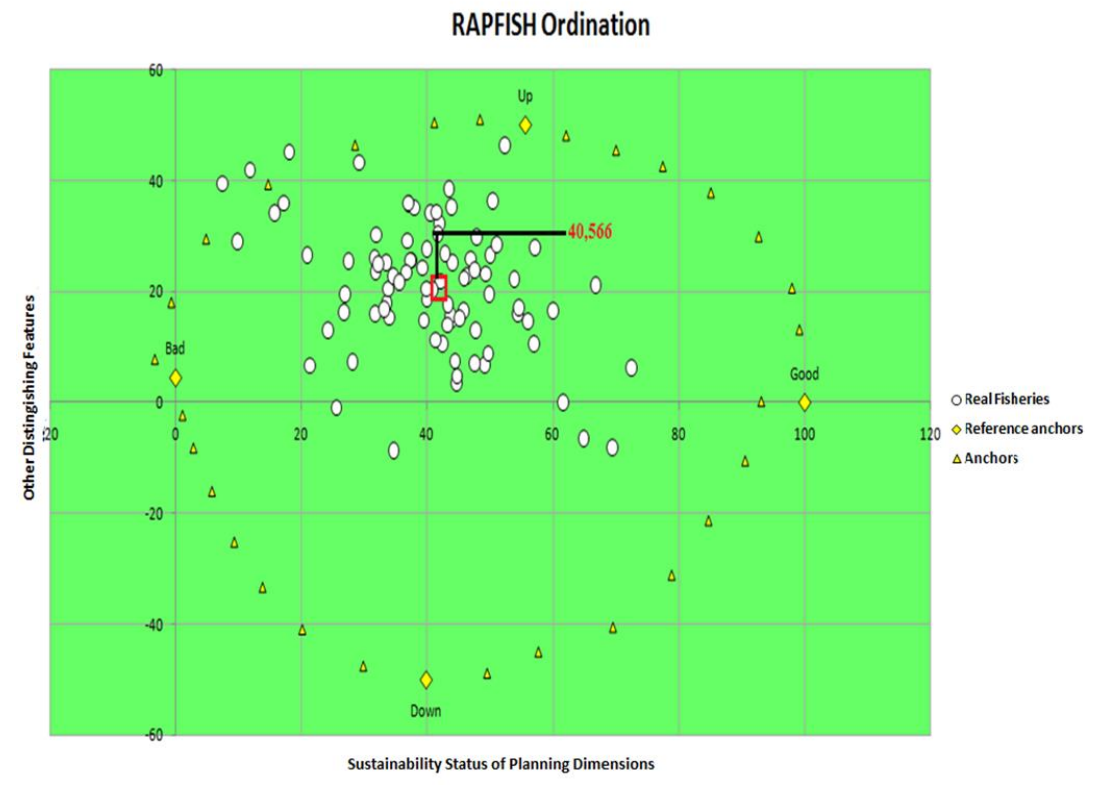

Figure 2. Sustainability Status of the Planning 


\section{Leverage of Attributes Planning Dimension}

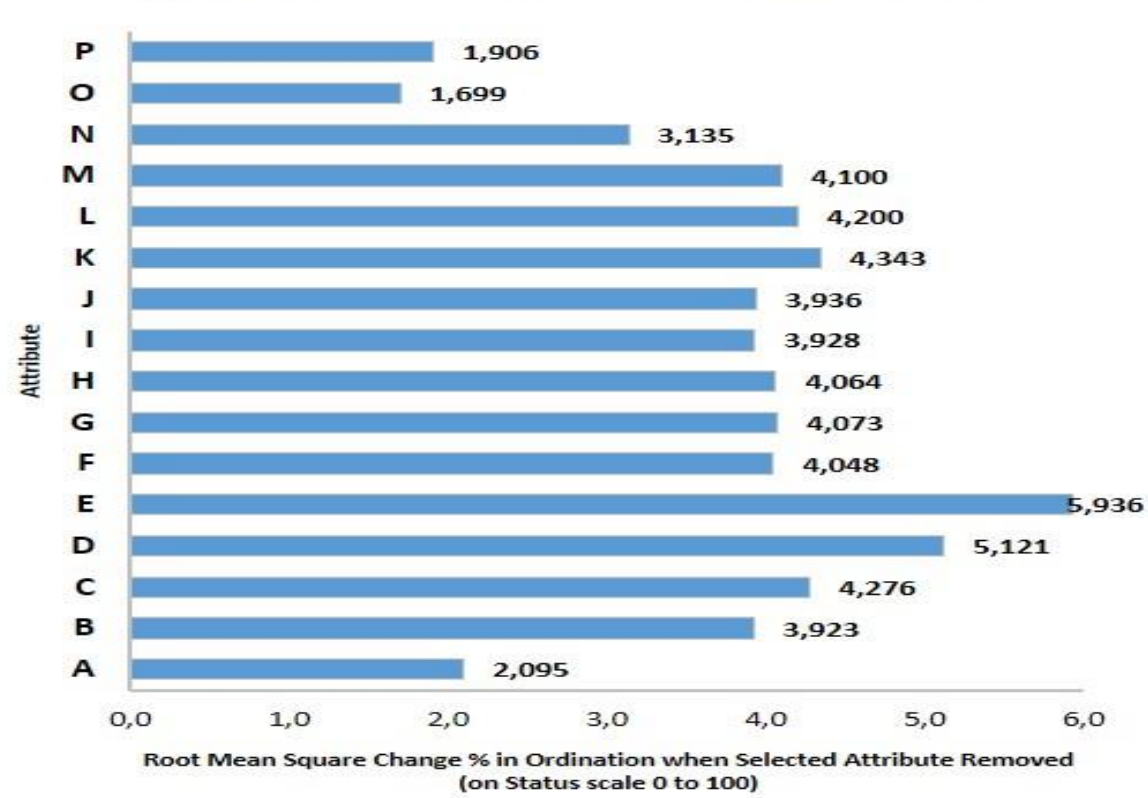

Figure 3. Planning Dimension Leverage

\section{Description:}

A : The community does not have the authority to submit proposals for ecotoursm development.

B: There is opportunity for the community to submit proposal in planning ecotourism development, but there is no willingness from the community to submit proposal.

C: There are proposals from the community in planning ecotourism development, but only modestly (as long as they submit proposals).

D : The community could submit proposals in planning ecotourism development, but there is no guarantee that the idea will be realized in the program to be implemented.

E : The community could submit proposals in planning ecotourism development, but had very little opportunity to influence the program to be implemented.

F : The community proposals considered in the plan to develop ecotourism in the Taman Beach area are synergized with the Regional Government program and can be implemented.

G : The community proposals have been considered in the plan for developing ecotourism in the Taman Beach area, but have not yet been prioritized.

$\mathrm{H}$ : The proposals submitted by the community can be accepted and implemented in the ecotourism development program in the Taman Beach.

I: Planning for developing ecotourism in the Taman Beach area there is not dialogue or consultation with the community.

$\mathrm{J}$ : The community does not get the opportunity for discussion / deliberation, but gets information on ecotourism development planning policies in the Taman Beach area.

$\mathrm{K}$ : The community only gets information on ecotourism development planning in the coastal area of the Park, but there is no opportunity for joint decisions (discussions are conducted in one direction).

$\mathrm{L}$ : The community has the opportunity to discuss ecotourism development planning, but the results are not taken into account.

$\mathrm{M}$ : The community has the opportunity to discuss planning for ecotourism development, with direction from the Regional Government.

$\mathrm{N}$ : The community gets the opportunity to discuss and submit ideas / ideas for planning ecotourism development, but the result are little that counts.

$\mathrm{O}$ : The community actively enganges in discussions, and has the authority to mske planning decisions on ecotourism development.

$\mathrm{P}$ : The community actively conducts discussions, and is able to make planning decisions on ecotourism development.

Index and Sustainability Status of the Management Dimension

The results of the MDS-RAPFISH analysis provide a sustainability index value of 47.146 , as can be seen in Figure 4. The index value is in the range of 25.00 - 49.99, which means this dimension is of a less sustainable. In other words, the involvement of community participation in supporting ecotourism development seen from the management dimension in the research area is less support the sustainability. 


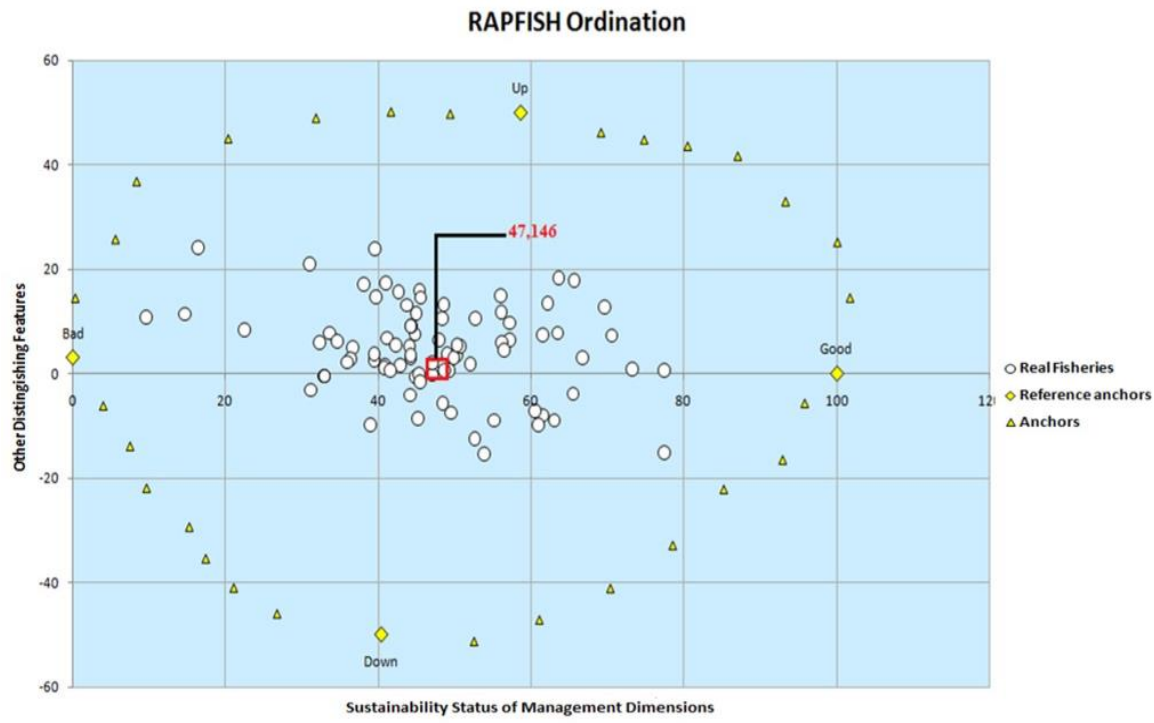

Figure 4. Sustainability Status Management Dimension

Based on the results of the Leverage analysis, three attributes were sensitive to the sustainability index value as shown in Figure $5: 1$ ) cooperation between the government and the community in managing Taman Beach ecotourism, and sharing authority, 2) government cooperation with the community in management of coastal Taman ecotourism, with guidance from the Regional Government, 3) the community gets very limited information and guidance on the development of the ecotourism of the Taman Beach.

\section{Leverage of Attributes Management Dimension}

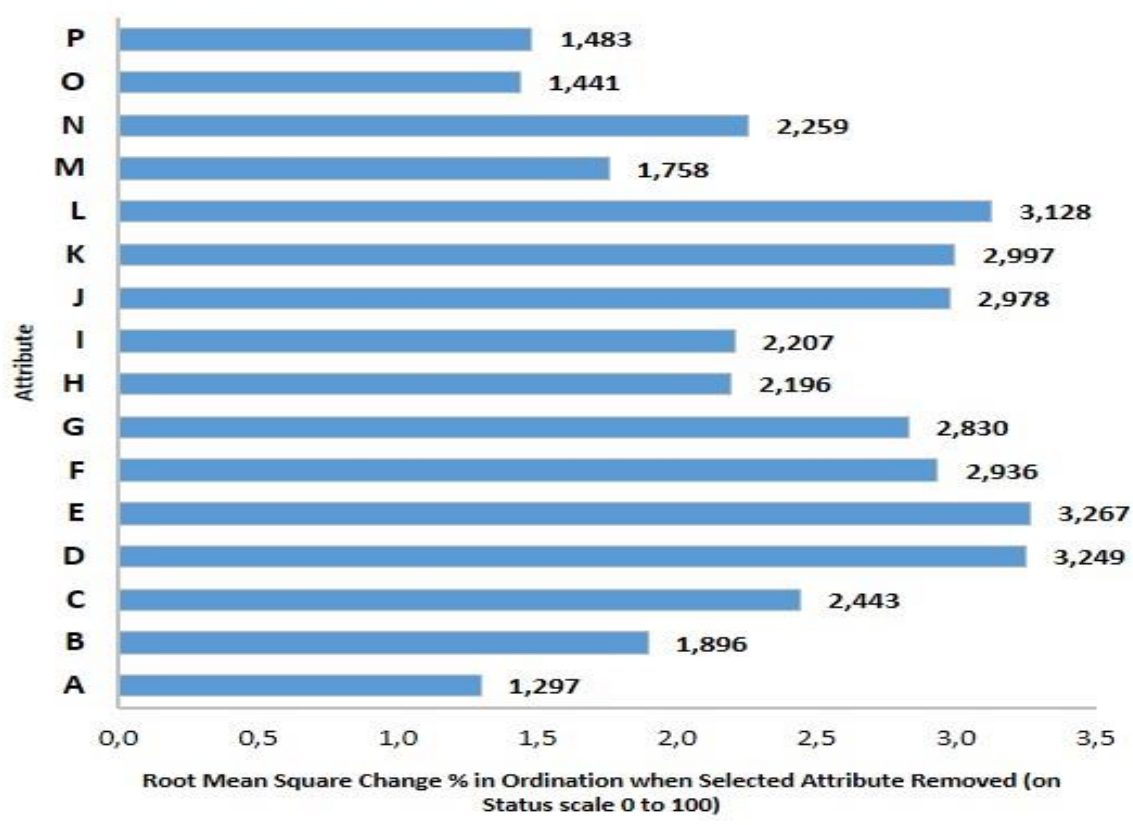

Figure 5. Results of Management Dimension Leverage Analysis

Description :

A : The community is not involved in managing the development of Taman Beach ecotourism

$B$ : Communities are involved in managing ecotourism by force.

C : The community is involved in managing Taman Beach ecotourism only for certain purposes.

D : Government cooperation with the community in management of coastal Taman ecotourism, with guidance from the Regional Government. 
E : Cooperation between the government and the community in managing Taman Beach ecotourism, and sharing authority.

$\mathrm{F}$ : The existence of government cooperation with the community in the management of Taman Beach ecotourism, with direction from the Regional Government.

G : Management of Taman Beacch ecotourism is fully carried out at the initiative of the community and given full responsibility.

$\mathrm{H}$ : The management of Taman beach ecotourism is fully carried out at the initiative of the community and contributes to their wealth, energy and time.

I: The community does not get information and direction about the development of Taman beach ecotourism.

$\mathrm{J}$ : The community gets information and direction about developing Taman beach ecotourism, but the community has not responded.

$\mathrm{K}$ : Communities get information and direction about the development of ecotourism beach parks as perfunctory.

$\mathrm{L}$ : The community gets very limited information and guidance on the development of the ecotourism of the Taman Beach.

$\mathrm{M}$ : The community gets information and direction on developing Taman beach ecotourism regularly.

$\mathrm{N}$ : The community gets information / direction about developing Taman beach ecotourism and contributes to disseminating this information.

$\mathrm{O}$ : The community gets information / direction about developing Taman beach ecotourism and actively disseminates it for the benefit of the development of Taman beach.

$P$ : The community gets information / direction about developing Taman beach ecotourism and is able to innovate to develop it to be sustainable

Index and Sustainability Status of the Monitoring and Controlling Dimension

Based on the results of the analysis using MDS-Rapfish, the sustainability index value for monitoring and controlling dimensions is 45.394, as can be seen in Figure 6 . The index value is in the range of $25.00-49.99$, which means that this dimension is less sustainable. In other words, the involvement of community participation in supporting ecotourism development seen from the dimensions of monitoring and controlling in the research area is less support to sustainability.

\section{RAPFISH Ordination}

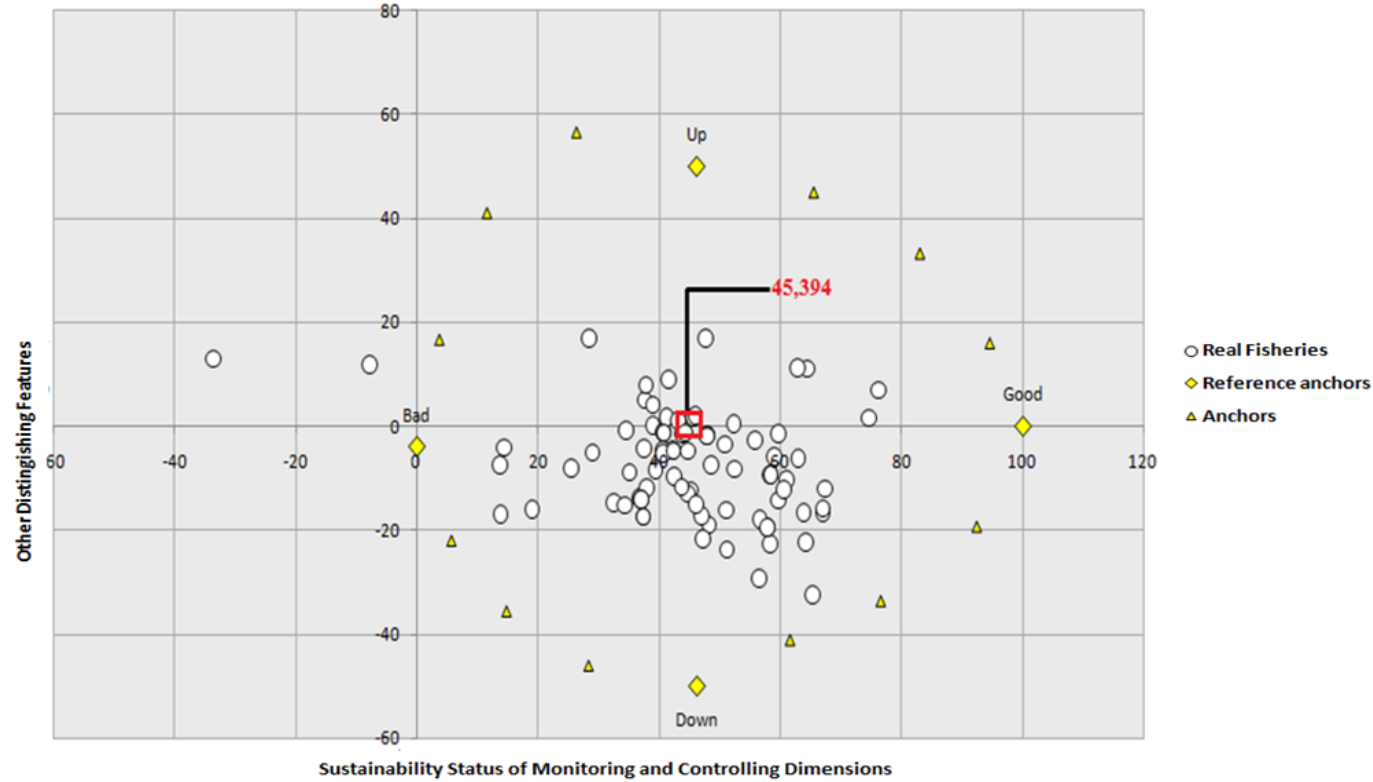

Figure 6. Sustainability Status of Monitoring and Controlling Dimensions

Based on the results of the Leverage analysis, three attributes that are sensitive to the environmental dimension index value are : 1) the community participates in monitoring and controlling the management of limited Taman ecotourism in the interests of the Regional Government, 2) the community participates in monitoring and controlling the management of Taman Beach ecotourism due to force. Leverage analysis results can be seen in Figure 7 . 


\section{Leverage of Attributes Monitoring and Controlling Dimension}

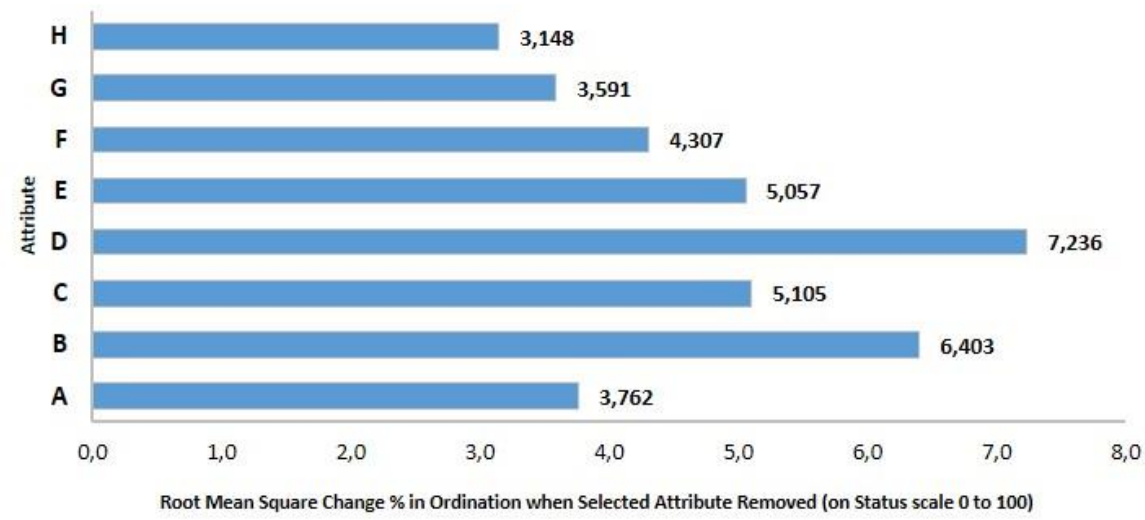

Description :

Figure 7. Dimension of Monitoring and Controlling Leverage

A : The community is not involved in monitoring and controlling the management of Taman beach ecotourism.

B : The community participates in monitoring and controlling the management of Taman Beach ecotourism due to force.

C: The community participates in monitoring and controlling the management of just a small amount of coastal ecotourism.

D : The community participates in monitoring and controlling the management of limited Taman ecotourism in the interests of the Regional Government.

E : The community participates in monitoring and controlling the management of Taman beach ecotourism on its own accord and has the same responsibilities.

$\mathrm{F}$ : The community participates in monitoring and controlling the management of Taman beach ecotourism on a regular basis on its own accord and has greater responsibility than the Regional Government.

$G$ : The community participates in monitoring and controlling the management of Taman beach ecotourism and is aware of the importance of the responsibility to participate in keeping it to be sustainable.

$\mathrm{H}$ : Monitoring and controlling of the management of Taman beach ecotourism is fully carried out by the community and actively take care of / maintains it to be sustainable.

\section{Status of Sustainability Multidimensional Community Participation}

Based on the results of MDS-Rapfish analysis, the sustainability index value in community participation of Taman Beach, which consists of a combination of three dimensions, has an average sustainability index value of 44.369 , as shown in Figure 8. This shows the education on the Taman beach is included in the unsustainable category, which included in the scale of 25.00 - 49.99.
The most superior dimension is the planning dimension, while the dimensions that have the lowest sustainability index are monitoring and controlling. Therefore, the issue of monitoring and supervision in particular needs to be given more serious attention so that the development of community participation in ecotourism on the Taman beach can be sustainable.

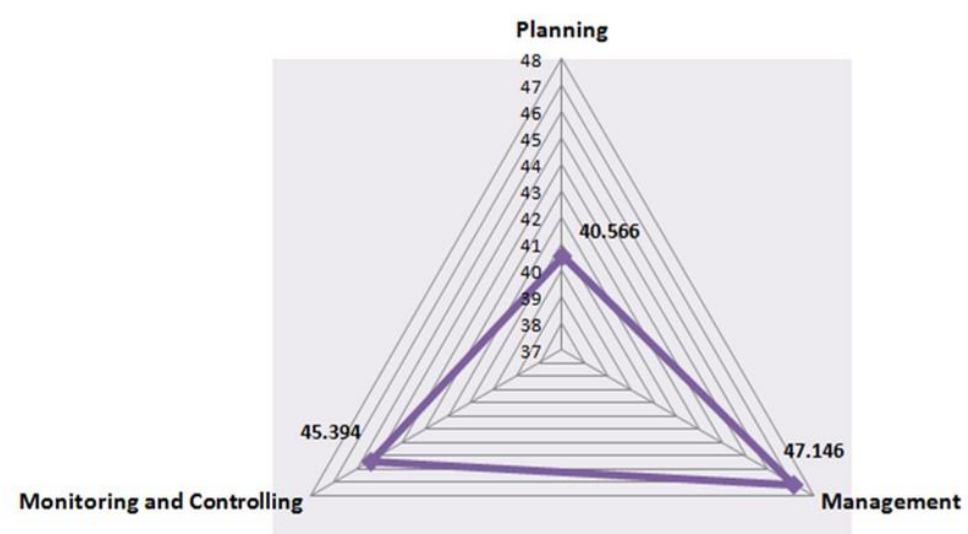

Figure 8. Kite Diagram of Sustainability Index Value from Three Dimensions of Community Participation in Taman Beach 
To achieve a sustainable community participation there must be a balance between the dimensions of planning, management, monitoring and controlling [3]. Improvements to sensitive attributes affect especially the sustainability index values of these three dimensions need to be improved so that the value of this index in the future continues to increase until it reaches a balanced sustainable status [11].

Furthermore, to see the level of errors in the analysis of RAPFISH with MDS, the validity test was carried out using the Monte Carlo analysis method with a confidence level of $95 \%$. Based on Table 4, it can be seen that the index of sustainability of community participation in ecotourism at Taman Beach shows a small difference in the value of the two analyzes (2.378\%). This small difference in value indicates that errors in the analysis process can be minimized or avoided and RAPFISH's ordination analysis results are in a stable and uninterrupted position both in each dimension and in a combination of overall sustainability dimensions so that it can explain the sustainability of community participation in ecotourism in beach park.

Table 4. Difference in RAPFISH Analysis Sustainability Index Value with Monte Carlo Analysis

\begin{tabular}{lccc}
\hline $\begin{array}{c}\text { Sustainability } \\
\text { Dimension }\end{array}$ & $\begin{array}{c}\text { MDS } \\
\text { result }\end{array}$ & $\begin{array}{c}\text { Monte } \\
\text { Carlo } \\
\text { result }\end{array}$ & $\begin{array}{c}\text { MDS-MC } \\
\text { difference }\end{array}$ \\
\hline Planning & 40.566 & 42.275 & 1.709 \\
Management & 47.146 & 50.436 & 3.290 \\
Monitoring & 45.394 & 47.529 & 2.135 \\
and & & & \\
Controlling & & & \\
\hline Average & $\mathbf{4 4 . 3 6 9}$ & $\mathbf{4 6 . 7 4 7}$ & $\mathbf{2 . 3 7 8}$ \\
\hline
\end{tabular}

Strategies for Increasing Community Participation

Based on the results of the analysis, several strategies can be developed to maintain and improve the sustainability status of community participation while prioritizing the local culture and local wisdom.

\section{Planning Dimension}

The strategy for increasing community participation in ecotourism development is seen from the planning aspects, as follows:

a. Improve the planning process and the development of the Taman Beach ecotourism through a bottom up planning approach starting from the Village development planning meetings (Musrenbang) process, District Musrenbang and District Musrenbang.

b. Involving all stakeholders in the development planning process and development of the coastal Park ecotourism in development Musrenbang starting at the village, subdistrict and district levels.

\section{Management Dimension}

Strategies for increasing community participation in the development of ecotourism on the coast of Taman from the management dimension include:

a. Increasing cooperation by giving greater responsibility and authority to the community in the management of ecotourism at the Taman beach.

b. Providing information and direction and information to the community in efforts to develop and develop ecotourism at the Taman Beach.

\section{Monitoring and Controlling Dimension}

The strategy to increase community participation in the development of ecotourism on the Taman Beach from the monitoring and supervision dimensions includes:

a. Giving greater responsibility to the community around the Taman Beach to monitor and control ecotourism activities on the Taman Beach.

b. Increasing public awareness to be involved in monitoring ecotourism activities at the Taman beach.

\section{Level of Community Participation}

The form of community participation seen from the aspect of ecotourism planning begins when submitting proposals in the context of the development and development of turtle conservation ecotourism. The community has had the opportunity to submit a proposal for an ecotourism development plan on the Park coast, even though it has very little chance and there is no guarantee that the proposal will be implemented. The government has actually paid attention to the proposals of the community, but priority has not yet been taken to be implemented and the realization is carried out in stages in accordance with regional financial capacity. 
In addition, the community did not get the opportunity for discussion/deliberation and joint decision-making in its development and development plans, but was informed of development planning policies and ecotourism development in the coastal area of Taman. Thus viewed from the aspect of planning, the community can submit a proposed development plan even though the opportunity is small and no guarantee is realized and has not been involved in discussion or deliberation, so it can be concluded that community participation seen from the planning aspect has reached the level of participation in the tokenism category (accept the terms) [3,8].

\section{CONCLUSION}

The sustainability index value of the level of community participation in multidimensional ecotourism management is 46.864 or less sustainable. In other words, community involvement in ecotourism does not support sustainability. The index value and sustainability status of each dimension, namely the planning dimension is the most superior dimension of 48.021 (less sustainable), the management dimension is 46.636 (less sustainable), the monitoring and controlling dimension is the lowest dimension of 45.936 (less sustainable).

The level of community participation in Arnstein's participatory ladder from the aspect of planning and management aspects has reached the level of participation of placations included in the tokensim category (accepting provisions). Whereas from the aspect of monitoring and supervision it has reached the level of consultation participation which is included in the tokenism category (accepting provisions).The alternative policy strategy for increasing community participation is through increasing the role and responsibility of the community in planning, management, monitoring and controlling.

\section{REFERENCES}

[1] Stone, M. T.. 2015. Community-based ecotourism: a collaborative partnerships perspective. Journal of Ecotourism 14(2), 166-184.

[2] Prihanta, W., A. Syarifuddin, A. M. Zainuri. 2017. Pembentukan kawasan ekonomi melalui pengembangan ekowisata berbasis masyarakat. Jurnal Dedikasi 14, 73-84.

[3] Hakim, L. and M. Soemarno. 2017. Biodiversity conservation, community development and geotourism development in Bromo-Tengger-Semeru-Arjuno Biosphere Reserve. Geojournal of Tourism and Geosites 20(2), 220-230.

[4] Mearns, K. F. 2010. The sustainability of community-based ecotourism in Southern Africa. Thesis. School of Environmental Design and Management. Faculty of Technology. University of Portsmouth, UK.

[5] Jamaluddin, A. N. 2015. Sosiologi perkotaan: memahami masyarakat kota dan problematikanya. Pustaka Setia.Bandung.

[6] Untari, R. 2009. Strategi pengembangan ekowisata berbasis masyarakat di zona wisata Bogor Barat Kabupaten Bogor. Master Thesis.Study Program of Natural Resource and Environmental ManagementPostgraduate School, Bogor Agricultural University. Bogor.

[7] Himberg, N. 2006. Community-based ecotourism as a sustainable development option in the Taita Hills, Kenya. Thesis. Department of Geography, University of Helsinki. Finland.

[8] Auesriwong, A., A.Nilnoppakun and W. Parawech. 2015. Integrative participatory community-based ecotourism at Sangkhom District, Nong Khai Province, Thailand. Procedia Economics and Finance23, 778-782.

[9] Arnstein, S. R. 1969. A ladder of citizen participation. Journal of the American Planning Association 35(4), 216-224.

[10] Pitcher, T.J. and D. Preikshot. 2001. RAPFISH : A Rapid Appraisal Technique to Evaluate the Sustainability Status of Fisheries. Fisheries Research 49(3), 255270.

[11] Parmawati, R., A. Qur'ania, A. K. Riarmanto, A. Yakub and A. S. Kurnianto. 2018. Interpretation of sustainability factor in Wonorejo Mangrove Ecotourism, Surabaya, Indonesia. Journal of Indonesian Tourism and Development Studies 6(1), 17-22. 